\title{
KONTRIBUSI USAHATANI SAPI PERAH TERHADAP PENERIMAAN RUMAH TANGGA PADA KELOMPOK TANI TERNAK PANGUDI MULYO DI KECAMATAN GUNUNGPATI, KOTA SEMARANG
}

\section{Contribution of Dairy Cow on Household Incomes of Pangudi Mulyo Livestock Farmer Group in Gunungpati Semarang}

\author{
M. Yaser Afrizzal ${ }^{1)}$, Kustopo Budiraharjo ${ }^{2)}$, Wiludjeng Roessali ${ }^{3)}$ \\ ${ }^{1,2,3)}$ Program Studi S1 Agribisnis, Fakultas Peternakan dan Pertanian, \\ Universitas Diponegoro, Semarang \\ Email: myaserafrizzal@ students.undip.ac.id
}

Submit: 15 Juli 2020, Revised: 6 Agustus 2020, Accepted: Agustus 2020

\begin{abstract}
Pangudi Mulyo livestock farmers group was established in 2000 proposed by the Semarang City Agriculture Office. This research was conducted in Pangudi Mulyo livestock farmers group which run dairy farming system and sited in Randusari dukuh, Nongkosawit village, Gunungpati district of Semarang. The purpose of this study was to determine the level of income, factors influencing the income and its contribution to the household income of Pangudi Mulyo farmer group member. The research location was purposively determined. Data was collected through observation and interview which then analyzed using descriptive and quantitative analysis such as profitability and multiple linear regressions. The independent variables measured were feed $(\mathrm{x} 1)$, number of lactation cows (x2), milk production (x3) and labor (x4). The average production cost spent was IDR 3,552,494 per month with the average revenue of each member of the farmer group was IDR 7,014,278 per month. At 95\% profitability, the average income earned of the dairy cattle business was then IDR $3,462,117$ per month contributing to $75 \%$ of the household income. Feed, number of lactation cows, milk production and labor are those factors which have a simultaneous effect on income whereas feeding and milk production factors only partially affect the income.
\end{abstract}

Keywords: Dairy Cattle; Production Factors; Profitability; and Revenue Contribution.

\section{ABSTRAK}

Kelompok Tani Ternak Pangudi Mulyo didirikan pada tahun 2000 atas usulan Dinas Pertanian Kota Semarang. Penelitian ini dilakukan di Kelompok Tani Ternak Pangudi Mulyo, Dukuh Randusari, Kelurahan Nongkosawit, Kecamatan Gunungpati, Semarang. Tujuan dari penelitian ini untuk menganalisis tingkat pendapatan, faktor-faktor yang mempengaruhi pendapatan dan kontribusi usahatani sapi perah terhadap pendapatan rumah tangga paada kelompok tani Pangudi Mulyo. Metode yang digunakan untuk menentukan lokasi dipilih dengan purposive (dipilih secara sengaja). Metode yang digunakan untuk pengumpulan data adalah observasi dan wawancara. Metode analisis data yang digunakan dalam penelitian adalah menggunakan analisis deskriptif dan kuantitatif. Analisis yang digunakan penelitian ini adalah analisis pendapatan usahatani sapi perah, profitabilitas dan regresi linier berganda untuk mengukur pengaruh antara variabel bebas yaitu pakan (x1), jumlah sapi laktasi $(\mathrm{x} 2)$, produksi susu $(\mathrm{x} 3)$ dan tenaga kerja $(\mathrm{x} 4)$. Hasil penelitian rata-rata biaya produksi yang 
dikeluarkan sebesar Rp 3.552.494,-/ bulan. Rata-rata penerimaan anggota KTT Pangudi Mulyo sebesar Rp 7.014.278,-/ bulan. Rata-rata pendapatan yang didapatakan sebesar Rp 3.462.117,-/ bulan. Rata-rata Profitabilitas usaha ternak sapi perah KTT Pangudi Mulyo sebesar 95\%. Kontribusi pendapatan usaha ternak sapi perah terhadap pendapatan rumah tangga sebesar 74\%. Faktor pakan, jumlah sapi laktasi, produksi susu dan tenaga kerja berpengaruh serempak terhadap pendapatan. Faktor pakan dan produksi susu berpengaruh secara parsial terhadap pendapatan.

Kata Kunci: Faktor Produksi; Kontribusi Pendapatan; Profitabilitas dan Sapi Perah.

\section{PENDAHULUAN}

Usahatani merupakan suatu kegiatan organisasi yang meliputi alam, kerja dan modal yang ditunjukan kepada para produksi pertanian (Duarah and Mall, 2020; Kingwell et al., 2020). Pertanian memiliki arti luas yaitu campur tangan manusia untuk memenuhi kebutuhannya dengan mengembangkan tumbuh-tumbuhan dan hewan. Sektor pertanian khususnya usaha ternak sapi perah mempunyai prospek yang baik untuk dikembangkan menjadi sebuah usaha untuk meningkatkan perekonomian (Alhaji et al., 2020; Gengler, 2019; Unakitan and Kumbar, 2019). Bertambahnya penduduk serta meningkatnya perekonomian membuat masyarakat mulai menyadari bahwa susu sapi perah dapat mencukupi kebutuhan protein hewani dalam memenuhi gizi yang seimbang (Jarwanta et al,. 2012)

Pengelolaan usaha ternak sapi perah pada peternak rakyat di Indonesia masih mengalami banyak kekurangan yang megakibatkan kuantitas dan kualitas produksi susu (Adler et al., 2019; Berry et al., 2020; Ma et al., 2020). Produktivitas usaha sapi perah dapat dipengaruhi oleh beberapa faktor yaitu kurangnya modal, jumlah ternak, rendahnya infrastruktur, kurangnya pengetahuan peternak dalam mengelola sapi perah seperti pemarahan, pemberian pakan ternak, sanitasi dan pencegahan penyakit (Agusta et al,. 2014).

Jenis sapi perah yang paling banyak dibudidayakan di Indonesia adalah sapi perah Peranakan Friesian Holstein atau sering disebut dengan sapi PFH (Breider et al., 2019; Nyman et al., 2019; van Gastelen et al., 2018). Sapi PFH ini merupakan sapi perah dengan produksi susu yang cukup tinggi. Selain itu, sapi PFH mempunyai kemampuan adaptasi yang baik terhadap lingkungan tropis seperti Indonesia ini (Zainudin et al., 2014). Menurut data Badan Pusat Statistika Indonesia 2018 produksi susu sapi perah di Indonesia pada tahun 2016 sebesar 912,735 (ton), pada tahun 2017 sebesar 920,093 (ton) menunjukan bahwa setiap tahun produksi susu sapi perah meningkat. Sentra produksi susu sapi perah berada di Pulau Jawa, Jawa Timur sebagai penghasil tertinggi sebesar 501,325 ton, Jawa Barat sebesar 293,356 ton dan Jawa Tengah sebesar 106,938 ton (BPS Indonesia, 2018).

Kota Semarang merupakan salah satu kota di Jawa Tengah yang mengembangkan usaha ternak sapi perah. Menurut data (BPS Indonesia, 2018). Jumlah populasi sapi perah di Kota Semarang sebanyak 1.699 ekor. Daerah di Kota Semarang yang memiliki jumlah populasi sapi perah terbesar yaitu Kecamatan Gunungpati sebesar 886 ekor diikuti dengan Kecamatan Mijen sebesar 405 ekor dan Kecamatan Banyumanik 210 ekor (BPS Kota Semarang, 2018).

Tujuan dilaksanakan penelitian ini adalah menganalisis tingkat pendapatan usahatani sapi perah dan kontribusinya terhadap penerimaan keluarga petani ternak dan faktor produksi yang mempengaruhi pendapatan usahatani sapi perah pada kelompok tani ternak Pangudi Mulyo di Kecamatan Gungungpati.

\section{METODE PENELITIAN}

Penelitian dilakukan pada bulan Desember 2019 sampai Januari 2020 di kelompok tani ternak Pangudi Mulyo di Kecamatan Gunungpati, Kota Semarang. Lokasi penelitian ditentukan di Kecamatan 
Gunungpati secara purposive karena sentra produksi susu sapi di Kota Semarang. Penetapan penelitian pada. Kelompok Tani Ternak Pangudi Mulyo merupakan salah satu kelompok tani yang aktif, yang mempunyai jumlah ternak kurang lebih 145 ekor.

Metode penelitian studi kasus dengan menjadikan seluruh anggota kelompok tani sebagai responden. Jumlah responden peternak sapi perah sebanyak 30 orang. Metode pengumpulan data primer melalui observasi dan wawancara dengan panduan kuesioner. Data sekunder diperoleh dari data-data yang didapat dari sumber lain yang berfungsi sebagai data pendukung, diperoleh dari buku-buku maupun laporan hasil penelitian dan data dari BPS.

\section{Metode Analisis Data}

Metode analisis data yang digunakan dalam penelitian adalah menggunakan analisis deskriptif dan kuantitatif. Analisis yang digunakan penelitian ini adalah analisis pendapatan usahatani sapi perah, profitabilita.

Profitabilitas dihitung dengan mengunakan rumus (Ekowati et al., 2014):

Profitabilitas $=\frac{\text { Pendapatan Bersih }}{\text { Biaya Total }} \times 100 \%$

dimana profitabilitas diperoleh dari pendapatan bersih (PB) dibagi dengan Total Cost (TC) dikali 100\%.

\section{Pendapatan Usahatani}

Pengeluaran usahatani dihitung dengan menggunakan rumus (Ekoati et al,. 2014)

$\mathrm{TC}=\mathrm{FC}+\mathrm{VC}$

Dimana pengeluaran usahatani

(TC) diperoleh dari biaya tetap (FC) dijumlah dengan biaya variabel (VC)

Penerimaan usahatani dihitung dengan menggunakan rumus (Ekoati et al,. 2014)

$\mathrm{TR}=\mathrm{Y} \times \mathrm{Py}$

Dimana penerimaan usahatani sapi perah (TR) diperoleh dari susu, pedet, penjualan sapi dan nilai tambah sapi (Y) dikali dengan harga yang diterima (Py)

Pendapatan Usahatani sapi perah dihitung dengan menggunakan rumus (Ekoati et al,. 2014)
$\mathrm{P}=\mathrm{TR}-\mathrm{TC}$

Dimana pendapatan usahatani sapi perah (P) diperoleh dari selisih antara penerimaan (TR) dengan pengeluaran (TC)

Kontribusi Pendapatan Usaha Sapi Perah Terhadap Total Pendapatan Rumah Tangga dihitung dengan rumus :

$$
\text { Kontribusi }=\frac{\text { Pendapatan Usaha Sapi Peral }}{\text { Total Pendapatan Keluarga }} \times 100 \%
$$

Pendapatan usaha sapi perah adalah pendapatan yang diperoleh dari selisih antara penerimaan dengan biaya yang dikeluarkan. Total pendapatan keluarga adalah pendapatan yang diperoleh dari pendapatan usahatani sapi perah, pendapatan pertanian dan pendapatan non pertanian. Pendapatan non usahatani sapi perah sebagai petani, kuli bangunan, ojek online dan buruh angkut.

Faktor-faktor produksi terhadap pendapatan peternak sapi perah dianalisis menggunakan linier berganda dengan variabel bebas adalah pakan (x1), jumlah sapi laktasi (x2), produksi susu (x3) dan tenaga kerja (x4) terhadap variabel terikat yaitu pendapatan usahatani sapi perah. Persamaan regresi yang digunakan dapat dituliskan dalam rumus sebagai berikut:

$Y=a+b_{1} X_{1}+b_{2} X_{2}+b_{3} X_{3}+b_{4} X_{4}+u$ dimana :

$$
\begin{array}{ll}
\mathrm{Y} & =\text { Pendapatan usahatan (Rp/bulan) } \\
\mathrm{X} 1 & =\text { Hijauan }(\mathrm{kg}) \\
\mathrm{X} 2 & =\text { Jumlah Sapi Laktasi (ekor) } \\
\mathrm{X} 3 & =\text { Produksi susu (liter) } \\
\mathrm{X} 4 & =\text { Tenaga Kerja (HOK) } \\
\mathrm{a} & =\text { Konstanta } \\
\mathrm{b}_{1}-\mathrm{b}_{4} & =\text { Koefisien Regresi } \\
\mathrm{u} & =\text { error term }
\end{array}
$$

Analisis dilakukan setelah melakukan uji normalitas dan asumsi klasik Uji F dilakukan untuk mengetahui pengaruh variabel bebas secara serempak, dan uji $t$ untuk mengetahui pengaruh masingmasing variabel bebas terhadap $\mathrm{Y}$. Koefisien determinasi $\left(\mathrm{R}^{2}\right)$ digunakan untuk menunjukkan sampai seberapa besar variansi variabel bebas yang dapat dijelaskan oleh variansi dari variabel terikat. 


\section{HASIL DAN PEMBAHASAN}

\section{Gambaran Umum Kelompok Tani Ternak Pangudi Mulyo}

Kelompok tani ternak (KTT) Pangudi Mulyo bergerak pada sektor agribisnis sapi perah. KTT tersebut terletak di Dukuh Randusari, RW 2, Kelurahan Nongkosawit, Kecamatan Gunungpati, Kota Semarang. KTT Pangudi Mulyo didirikan pada tahun 2000 atas usulan Dinas Pertanian Kota Semarang. Kelompok Tani Ternak Pangudi Mulyo merupakan salah satu kelompok yang mengembangkan usaha sapi perah di Kecamatan Gunungpati. Kelompok Tani Ternak (KTT) Pangudi Mulyo berlokasi di Dukuh Randusari, Kelurahan Nongkosawit, Kecamatan Gunungpati, Semarang. Jumlah anggota KTT Pangudi Mulyo berjumlah 30 anggota. Sapi perah yang dimiliki oleh KTT Pangudi Mulyo kurang lebih berjumlah 145 ekor, jenis sapi perah yang dibudidayakan yaitu jenis Peranakan Friesian Holstein (PFH), selain membudidayakan sapi perah KTT Pangudi Mulyo juga membudidayakan sapi potong. Rata-rata anggota KTT memiliki 5-6 ekor sapi perah. Produksi susu sapi perah per anggota KTT Pangudi Mulyo sekitar 10-30 liter perhari. Namun, petani mengalami permasalahan pada saat kemarau panjang, petani susah untuk mendapatkan air, ketersedian pakan yang tidak melimpah yang mengakibatkan produksi susu sapi menurun dan tidak dapat memenuhi jumlah permintaan konsumen. Konsumen dari KTT Pangudi Mulyo yaitu tengkulak dan masyarakat sekitar. Harga susu sapi perah berkisar Rp 6.000 - Rp
10.000 per liter. Mayoritas anggota KTT Pangudi Mulyo bermata pencaharian sebagai peternak sapi perah dan sebagai petani, kuli bangunan, ojek online dan buruh angkut. Penggunaan faktor-faktor produksi secara produktif, efektif dan efisien diharapkan dapat diperhatikan oleh para petani dalam menerapkan usahataniagari dapat memberikan profit yang semaksimal mungkin.

\section{Karakteristik Responden}

Responden dalam penelitian ini yaitu anggota KTT Pangudi Mulyo yang memelihara sapi perah yang berjumlah 30 orang. Karakteristik responden dapat ditentukan dengan beberapa indikator yaitu usia, pendidikan dan pengalaman bertenak. karakteristik responden menurut usia menunjukan usia mayoritas anggota KTT Pangudi Mulyo yaitu 41-50 tahun sebanyak 15 orang dan 51-60 sebanyak 13 orang. Hal ini sesuai dengan pendapat Susanti et $a l$. (2016) yang menyatakan bahwa usia produktif petani berada pada usia 30-59 tahun karena memiliki fisik yang potensial untuk mendukung kegiatan usahatani. Berdasarkan data penelitian diketahui bahwa karakteristik responden menurut tingkat pendidikan mayoritas anggota KTT Pangudi Mulyo adalah lulusan SD sebesar $60 \%$ atau 18 orang, lulusan SMP sebesar $30 \%$ atau 9 orang dan lulusan SMA sebesar $10 \%$ atau 3 orang.

\section{Biaya Produksi}

Berdasarkan hasil penelitian diperoleh hasil biaya produksi di KTT Pangudi Mulyo sebagai berikut:

Tabel 1. Total Rata-rata Biaya Produksi

\begin{tabular}{|c|c|c|c|c|c|}
\hline No & Komponen Biaya & Jumlah & Satuan & Harga & Persentase \\
\hline & & & & -Rp/bln- & $--\%--$ \\
\hline & Biaya Tetap & & & & \\
\hline 1 & Penyusutan Sapi & 6 & Umur & 208.460 & 5,86 \\
\hline 2 & Penyusutan Kandang & 1 & Buah & 31.396 & 0,88 \\
\hline 4 & Sewa & & & 50.000 & 1,40 \\
\hline 5 & Listrik Dan Air & & & 28.333 & 0,79 \\
\hline \multirow[t]{3}{*}{6} & Tenaga Kerja & 0,9239 & Hok & 1.940 .313 & 54,62 \\
\hline & Total Biaya Tetap & & & 2.258 .502 & \\
\hline & Biaya Variabel & & & & \\
\hline 1 & Hijauan & 44,5 & Ikat & 890.000 & 25,05 \\
\hline 2 & Komboran & 440 & $\mathrm{Kg}$ & 352.000 & 9,90 \\
\hline \multirow[t]{3}{*}{3} & Vitamin & 1 & Pcs & 51.667 & 1,45 \\
\hline & & & & 1.293 .667 & \\
\hline & Total Biaya Produksi & & & 3.552 .169 & 100 \\
\hline
\end{tabular}


Berdasarkan hasil penelitian diketahui rata-rata biaya produksi pada KTT Pangudi Mulyo sebesar Rp 3.552.169,-. Biaya produksi diperoleh dari jumlah biaya tetap ditambah jumlah biaya variabel. Biaya tetap terdiri dari penyusutan sapi, penyusutan kandang, biaya sewa lahan, listrik dan air serta tenaga kerja, sedangkan biaya variabel terdiri dari hijauan, komboran dan vitamin, Komboran merupakan campuran singkong, ampas tahu dan bekatul. Total biaya terbesar adalah tenaga kerja sebesar 54,2\% dan hijauan sebesar 25,05\%. Hal ini dibandingkan dengan besarnya penerimaan yang diteliti Achmad (2011) yang menyatakan bahwa biaya produksi pada Peternak Desa Cibeureum yang mempumyai persentase terbesar adalah biaya tenaga kerja sebesar $57,85 \%$ serta pakan ternak mempunyai persentase besar pada biaya produksi yaitu sebesar $30,26 \%$.

\section{Penerimaan}

Berdasarkan hasil penelitian diperoleh hasil penerimaan di KTT Pangudi Mulyo sebagai berikut:

Tabel 2. Total Rata-rata Penerimaan

\begin{tabular}{rlrr}
\hline \hline No & Penerimaan & Jumlah & Persentase \\
\hline & & -- Rp/bln-- & $--\%--$ \\
1 & Penjualan Susu & 3.886 .000 & 55,39 \\
2 & Pedet & 833.333 & 11,88 \\
3 & Penjualan Sapi & 1.847 .222 & 26,33 \\
4 & Nilai Tambah & 1.209 .722 & 17,25 \\
& & 7.014 .278 & 100,00
\end{tabular}

Berdasarkan hasil penelitian diketahui rata-rata penerimaan pada anggota KTT Pangudi Mulyo sebesar Rp 7.014.278,-. Hal ini dibandingkan dengan besarnya penerimaan yang diteliti oleh Achmad (2011) yang menyatakan bahwa total penerimaan usahatani sapi perah pada peternak di Desa Cibeureum, Kabupaten Bogor sebesar Rp 6.786.000,-. Penerimaan pada KTT Pangudi Mulyo berasal dari penjualan susu, pedet, penjualan sapi dan nilai tambah ternak. Hal ini sesuai dengan pendapat Rahayu et al., (2014) bahwa Penerimaan pada usahatani sapi perah berasal dari penjualan susu, penjualan sapi pedet, dewasa dan afkir.

\section{Pendapatan Usahatani Sapi Perah}

Berdasarkan hasil penelitian diperoleh hasil pendapatan usahatani sapi perah di KTT Pangudi Mulyo sebagai berikut :

Tabel 3. Total Rata-rata Pendapatan Usahatani Sapi Perah

\begin{tabular}{llc}
\hline \hline No & Pendapatan & Jumlah \\
\hline & & -- Rp/bulan-- \\
1 & Penerimaan & 7.014 .611 \\
2 & Biaya Produksi & 3.552 .494 \\
& Rata Pedapatan per bulan & 3.462 .117 \\
\hline
\end{tabular}

Berdasarkan hasil penelitian diketahui rata-rata pendapatan peternak anggota KTT Pangudi Mulyo sebesar Rp 3.462.117,-Pendapatan usahatani yang diterima oleh KTT Pangudi Mulyo sebanding dengan biaya yang dikeluarkan pada setiap bulan, KTT Pangudi Mulyo memperoleh keuntungan. Hal ini sesuai dengan pendapat Samsu (2013) yang menyatakan bahwa pendapatan adalah bagian terpenting pada penyajian akan informasi pada laporan dari laba rugi, jika pendapatan suatu perusahaan lebih besar dari biaya yang telah dikeluarkan atau dibebankan maka perusahaan itu dapat dikatakan untung (laba), sebaliknya jika pendapatan suatu perusahaan lebih kecil 
dari biaya yang dikeluarkan maka perusahaan rugi.

\section{Profitabilitas}

Berdasarkan hasil penelitian diketahui profitabilitas pada KTT Pangudi Mulyo sebesar 95\% yang menyatakan bahwa profitabilitas usahatani sapi perah dapat dikatakan untung. Profitabilitas usahatani sapi perah KTT Pangudi Mulyo didapatkan dari pendapatan selama satu bulan dan biaya produksi yang sudah dikeluarkan. Hal ini dibandingkan profitabilitas yang diteliti oleh Ningrum dan Suparmini (2015) yang menyatakan bahwa nilai profitabilitas usaha ternak sapi perah di Desa Sruni Kabupaten Boyolali sebesar 97,70\%. Berdasarkan hasil uji one sample t-test pada dengan membandingkan suku bunga bank deposito BRI yaitu 1,67\% diperoleh bahwa nilai signifikansi yang diperoleh sebesar 0,05 yang menunjukan bahwa $\alpha<$ 0,05 , artinya terdapat perbedaan signifikan. Usahatani sapi perah merupakan usaha yang dapat dipilih oleh KTT Pangudi Mulyo karena menguntungkan. Hal ini sesuai dengan pendapat Ambarsari et al., (2014) yang menyatakan bahwa tingkat profitabilitas yang baik yaitu apabila nilai profitabilitasnya lebih tinggi daripada tingkat suku bunga kredit bank, sebaliknya apabila nilai profitabilitas suatu usahatani lebih rendah daripada tingkat suku Bunga kredit bank maka tingkat profitabilitasnya dianggap tidak menguntungkan untuk kegiatan usahataninya

\section{Kontribusi Pendapatan Usahatani Sapi Perah}

Berdasarkan hasil penelitian diperoleh hasil kontribusi pendapatan usahatani sapi perah di KTT Pangudi Mulyo sebagai berikut :

Tabel 4. Total Rata-rata Kontribusi Pendapatan Usahatani Sapi Perah

\begin{tabular}{lcc}
\hline \hline \multicolumn{1}{c}{ Kontribusi Pendapatan } & Jumlah & Persentase \\
\hline & -- Rp-- & $--\%--$ \\
Pendapatan Usahatani Sapi Perah & 3.462 .117 & 74,08 \\
Pendapatan Non Usahatani Sapi Perah & 1.211 .357 & 25,92 \\
& 4.673 .475 & 100 \\
\hline
\end{tabular}

Mayoritas anggota KTT Pangudi Mulyo bermata pencaharian sebagai peternak sapi perah dan anggota KTT juga sebagaian bermata pencaharian sebagai petani, kuli bangunan, ojek online dan buruh angkut. Berdasarkan hasil penelitian diketahui kontribusi usahatani sapi perah pada KTT Pangudi Mulyo sebesar 74\% yang menyatakan bahwa usahatani sapi perah memberikan kontribusi terhadap pendapatan rumah tangga anggota KTT Pangudi Mulyo. Kontribusi pendapatan usaha sapi perah terhadap pendapatan keluarga termasuk katagori besar. Menurut Maghfira (2017) menyatakan bahwa range kontribusi pendapatan usahatani terhadap pendapatan rumah tangga dikatakan besar jika mempunyai range $50-75 \%$.

\section{Pengaruh Penggunaan Faktor-Faktor Produksi Terhadap Pendapatan Peternak Sapi Perah}

Faktor-faktor produksi yang digunakan dalam analisis regresi yaitu pakan $\left(\mathrm{X}_{1}\right)$, jumlah sapi laktasi $\left(\mathrm{X}_{2}\right)$, produksi susu $\left(\mathrm{X}_{3}\right)$ dan tenaga kerja $\left(\mathrm{X}_{4}\right)$. Berdasarkan analisis regresi linier berganda yang digunakan dalam penelitian dapat ditulis dalam persamaan sebagai berikut:

$$
\begin{aligned}
\mathrm{Y}= & -11.135,016+24.543,045 \quad \mathrm{X}_{1}- \\
& 412.572,024 \mathrm{X}_{2}+6.464,130 \mathrm{X}_{3}+ \\
& 382,681 \mathrm{X}_{4}
\end{aligned}
$$

Berdasarkan Tabel 5 diperoleh hasil uji F pada faktor-faktor produksi di Kelompok Tani Ternak Pangudi Mulyo memiliki nilai signfikansi sebesar 0,000. Nilai tersebut menunjukkan bahwa $\alpha \leq 0,05$ yang berarti variabel pakan, jumlah sapi laktasi, produksi susu dan tenaga kerja berpengaruh sangat nyata secara bersama-sama terhadap pendapatan peternak. Hal ini sesuai dengan pendapat Wardani et al. (2012) bahwa pengambilan keputusan pada uji $\mathrm{F}$ apabila $\alpha>0,05$ maka $\mathrm{H}_{0}$ diterima dan $\mathrm{H}_{1}$ ditolak sedangkan apabila sig. $\alpha \leq 0,05$ maka $\mathrm{H}_{0}$ ditolak dan $\mathrm{H}_{1}$ diterima artinya variabel 
bebas beperngaruh serempak terhadap variabel terikat.

Berdasarkan Tabel 5. diperoleh hasil uji t yaitu variabel pakan (X1) dan produksi susu (X3) memiliki nilai sig. $\alpha \leq$ 0,05 artinya variabel pakan berpengaruh nyata terhadap pendapatan peternak. Hal ini disebabkan karena pemberian pakan pada ternak disesuaikan dengan kebutuhan ternak agar produksi susu yang dihasilkan optimal sehingga mempengaruhi pendapatan peternak. Pada saat musim kemarau para peternak sapi perah terkadang membeli pakan untuk memenuhi kebutuhan sapi yang mengakibatkan penambahan biaya.

Nilai signifikansi yang diperoleh pada faktor produksi jumlah sapi laktasi sebesar 0,353 yang menunjukkan bahwa variabel jumlah sapi laktasi tidak berpengaruh terhadap pendapatan peternak. Hal ini disebabkan karena sapi laktasi menghasilkan produksi susu berbeda-beda sesuai dengan umur sapi dan masa produksinya. Produksi susu yang dihasilkan juga belum tentu maksimal apabila ternak sapi belum berada pada puncak masa produktif. Hal ini tidak sesuai dengan pendapat Wardani et al. (2012) bahwa penerimaan yang berasal dari penjualan susu dipengaruhi oleh jumlah ternak yang miliki, semakin banyak ternak yang dimiliki semakin banyak pula produksi susu yang dihasilkan akan berpengaruh terhadap penjualan susu sehingga dapat meningkatkan pendapatan.

Nilai signifikansi yang diperoleh pada variabel produksi susu sebesar 0,000 yang berarti bahwa variabel produksi susu berpengaruh sangat nyata terhadap pendapatan peternak. Hal tersebut disebabkan karena semakin tingg produksi susu yang dihasilkan maka semakin tinggi pula pendapatan yang akan diperoleh peternak dalam menjalankan kegiatan usaha ternak. Hal ini sesuai dengan pendapat Santosa et al. (2013) bahwa semakin tinggi jumlah produksi susu maka semakin tinggi penjualan susu yang akan berdampak pada peningkatan penerimaan.

Variabel tenaga kerja memperoleh nilai signifikansi sebesar 0,992 yang berarti bahwa variabel tenaga kerja tidak beperngaruh terhadap pendapatan peternak. Hal ini disebabkan karena penggunaan tenaga kerja pada usaha ternak berasal dari tenaga kerja keluarga sehingga relative lebih murah. Penggunaan tenaga kerja keluarga dilakukan karena peternak dianggap mampu untuk memelihara ternak. Hal ini sesuai dengan pendapat Rahayu (2013) bahwa penambahan jumlah tenaga kerja pada usaha ternak akan menurunkan pendapatan yang diperoleh peternak.

Koefisien determinasi digunakan untuk menentukan persentase total variasi dalam variabel terikat yang diterangkan oleh variabel bebas. Hasil koefisien determinasi dapat dilihat melalui nilai Adjusted $R$ Square. Berdasarkan hasil analisis diketahui nilai koefisien determinasi sebesar 0,761 atau $76,1 \%$. Nilai tersebut memiliki arti bahwa $76,1 \%$ variasi nilai pendapatan dijelaskan oleh variabel pakan, jumlah sapi laksatsi, produksi susu dan tenaga kerja sedangkan $23,9 \%$ dijelaskan oleh faktor lain di luar model regresi yang digunakan.

Tabel 5. Hasil Uji Regresi Linier Berganda

\begin{tabular}{|c|c|c|c|c|}
\hline No & Variabel & Koefisien & Thitung & Sig \\
\hline 1 & Konstanta & $-111,335,016$ & $-0,11$ & 0,991 \\
\hline 2 & Pakan & $24,543,045$ & 2,287 & $0,031 *$ \\
\hline 3 & Jumlah Sapi Laktasi & $412,572,024$ & $-0,946$ & 0,353 \\
\hline 4 & Produksi Susu & $6,464,130$ & 4,464 & $0,000 *$ \\
\hline 5 & Tenaga Kerja & 382,681 & 0,01 & 0,992 \\
\hline \multicolumn{5}{|c|}{$\mathrm{F}$ hitung $=24,041$} \\
\hline \multicolumn{5}{|c|}{ Sig $0.000 *$} \\
\hline \multicolumn{5}{|c|}{ Adjusted R Suare $=0,761$} \\
\hline
\end{tabular}




\section{KESIMPULAN}

Berdasarkan hasil penelitian yang telah dilakukan disimpulkan bahwa pendapatan peternak anggota KTT Pangudi Mulyo Rata-rata pendapatan yang didapatakan sebesar Rp 3.462.117,- tiap bulan. Profitabilitas usaha ternak sapi perah KTT Pangudi Mulyo sebesar 95\%. Kontribusi pendapatan usaha ternak sapi perah terhadap pendapatan rumah tangga sebesar 74\%. Faktor pakan, jumlah sapi laktasi, produksi susu dan tenaga kerja berpengaruh serempak terhadap pendapatan. Faktor pakan dan produksi susu berpengaruh secara parsial terhadap pendapatan, sedangkan faktor jumlah sapi laktasi dan tenaga kerja tidak berpengaruh secara parsial terhadap pendapatan usahatani sapi perah.

\section{DAFTAR PUSTAKA}

Achmad, F,A. 2011. Analisis Pendapatan Usahatani Dan Faktor-Faktor Yang Mempengaruhi Produksi Susu Sapi Perah Peternak Desa Cibeureum Kabupaten Bogor. Fakultas Ekonomi Dan Manajemen, Institut Pertanian Bogor (Skripsi)

Agusta Q,T., D, Aring dan S, Sitomurang. 2014. Analisis pendapatan dan tingkat kesejahteraan rumah tangga peternak sapi perah anggota Koperasi Peternakan Bandung Selatan (KPBS) Pangalengan. J. IIA. 2 (2): 109-117

Ambarsawi, W., B. Ismadi dan A. Setiadi. 2014. Analisis pendapatan bersih dan profitabilitas usahatani padi (Oryza sativa L.) di Kabupaten Indramayu. J. Agri Wiralodra 6 (2) : $19-27$.

Adler, F., Christley, R., Campe, A., 2019. Invited review: Examining farmers' personalities and attitudes as possible risk factors for dairy cattle health, welfare, productivity, and farm management: A systematic scoping review. Journal of Dairy Science 102, 3805-3824.

https://doi.org/10.3168/jds.2018-15037
Alhaji, N.B., Amin, J., Aliyu, M.B., Mohammad, B., Babalobi, O.O., Wungak, Y., Odetokun, I.A., 2020. Economic impact assessment of footand-mouth disease burden and control in pastoral local dairy cattle production systems in Northern Nigeria: A crosssectional survey. Preventive Veterinary Medicine 177, 104974.

https://doi.org/10.1016/j.prevetmed.20 20.104974

Badan Pusat Statistika Indonesia. 2016.Indonesia Dalam Angka. Kota Jakarta

Badan Pusat Statistika Indonesia. 2018. Indonesia Dalam Angka. Kota Jakarta

Badan Pusat Statistik Kota Semarang. 2018. Semarang Dalam Angka.Semarang

Badan Pusat Statistik Provinsi Jawa Tengah. 2018. Provinsi Jawa Tengah Dalam Angka. Provinsi. Kota Semarang

Berry, D.P., Ring, S.C., Twomey, A.J., Evans, R.D., 2020. Choice of artificial insemination beef bulls used to mate with female dairy cattle. Journal of Dairy Science 103, 1701-1710. https://doi.org/10.3168/jds.2019-17430

Breider, I.S., Wall, E., Garnsworthy, P.C., 2019. Short communication: Heritability of methane production and genetic correlations with milk yield and body weight in Holstein-Friesian dairy cows. Journal of Dairy Science $102,7277-7281$.

https://doi.org/10.3168/jds.2018-15909

Duarah, J.P., Mall, M., 2020. Diversified fish farming for sustainable livelihood: A case-based study on small and marginal fish farmers in Cachar district of Assam, India. Aquaculture 529, 735569.

https://doi.org/10.1016/j.aquaculture.2 $\underline{020.735569}$

Ekowati, T., D. Sumarjono, H. Setyawan dan E. Prasetyo. 2014. Usahatani. UPT UNDIP Pers, Semarang. 
Gengler, N., 2019. Symposium review: Challenges and opportunities for evaluating and using the genetic potential of dairy cattle in the new era of sensor data from automation. Journal of Dairy Science 102, 57565763. https://doi.org/10.3168/jds.201815711

Jarwanta, S., P. Kusriani dan E.S. Putri. 2012. Efisiensi faktor-faktor produksi usahatani sapi perah di KUD Jatinom Kecamatan Jatinom Kabupaten Klaten Jawa Tengah. J. Agrineca 12 (1) : 1630

Kingwell, R., Islam, N., Xayavong, V., 2020. Farming systems and their business strategies in south-western Australia: A decadal assessment of their profitability. Agricultural Systems 181, 102827.

https://doi.org/10.1016/j.agsy.2020.10 2827

Maghfira, A. 2017. Kontribusi Pendapatan Usahatani Bunga Krisan Terhadap Pendapatan Rumah Tangga Petani Di Kecamatan Bandungan Kabupaten Semarang. Fakultas Peternakan dan Pertanian Universitas Dionegoro Semarang. (Skripsi)

Mufriantie, F. dan A. Feriady. 2014. Analisis faktor produksi dan efisiensi alokatif usahatani bayam (Amarathus Sp) di Kota Bengkulu. J. Agrisep. 15 (1): 31 $-37$

Ma, W., Renwick, A., Zhou, X., 2020. Short communication: The relationship between farm debt and dairy productivity and profitability in New Zealand. Journal of Dairy Science S0022030220305191. https://doi.org/10.3168/jds.2019-17506

Nyman, S., Duchemin, S.I., de Koning, D.J., Berglund, B., 2019. Genome-wide association study of normal and atypical progesterone profiles in Holstein-Friesian dairy cows. Journal of Dairy Science 102, 3204-3215. https://doi.org/10.3168/jds.2018-15418

Rahayu, R,S,. W, Roessali. A, Setiadi dan Mukson. 2014. Kontribusi usaha sapi perah terhadap pendapatan keluarga peternak di Kecamatan Getasan Kabupaten Semarang. J. Agriekonomika. 3 (1): 45-54

Samsu, S. 2013. Analisis pengakuan dan pengukuran pendapatan berdasarkan PSAK no 23 pada PT. Misa Utara Manado J. EMBA. 1 (3): 567 - 575.

Santosa, S. I., A. Setiadi dan R. Wulandari. 2013. Analisis potensi pengembangan usaha peternakan sapi perah dengan menggunarolitkan paradigma agribisnis di Kecamatan Musuk Kabupaten Boyolali. J. Buletin Peternakan. 37 (2): 125 - 135.

Unakitan, G., Kumbar, N., 2019. Analysis of feed conversion efficiency in dairy cattle farms in Thrace Region, Turkey. Energy 176, 589-595. https://doi.org/10.1016/j.energy.2019.0 4.031

van Gastelen, S., Antunes-Fernandes, E.C., Hettinga, K.A., Dijkstra, J., 2018. The relationship between milk metabolome and methane emission of Holstein Friesian dairy cows: Metabolic interpretation and prediction potential. Journal of Dairy Science 101, 2110 2126. https://doi.org/10.3168/jds.2017$\underline{13334}$

Wardani, T. S., K. Budiharjo dan E. Prasetyo. 2012. Analisis profitabilitas pada peternakan sapi perah "Kurnia" Kediri. J. Peternakan. 1 (1): 339 - 357.

Zainudin, M., N. M. Ihsan dan Suyadi. 2014. Efisiensi reproduksi sapi perah $\mathrm{PFH}$ pada berbagai umur di CV. Milkindo Berka Abadi Desa Tegalsari Kecamatan Kepanjen Kabupate Malang. J. Ilmu-Ilmu Peternakan. 24 (3) : 32-37. 